\title{
Prolonged (more than ten hours) neuromuscular blockade after cardiac surgery: report of two cases
}

\author{
[Un blocage neuromusculaire prolongé (plus de dix heures) après une \\ intervention en cardiochirurgie : présentation de deux cas]
}

Lori Olivieri MD, Gilles Plourde MSc MD FRCPC

Purpose: We examine two cases of prolonged neuromuscular blockade (NMB) after cardiac surgery. To the best of our knowledge, these are the first reported cases of complete paralysis lasting more than ten hours after surgery.

Clinical features: We attribute the extended durations of NMB (more than ten hours) to high doses of NMB drugs in combination with magnesium sulphate and moderate renal failure. Advanced age, hepatic disease, aminoglycoside exposure, hypocalcemia, and possible interaction between rocuronium and pancuronium may have played minor roles.

Conclusion: We should avoid administering large doses of NMB agents, even in the context of planned postoperative ventilation. If $\mathrm{NMB}$ is not monitored intraoperatively in patients who are at risk of prolonged NMB, then train-of-four response should be measured in the intensive care unit. Adequate sedation should be provided until proper recovery of neuromuscular function is documented.

Objectif : Présenter deux cas de blocage neuromusculaire prolongé (BNM) après une intervention cardiaque. Selon nos connaissances, c'est la première publication de cas de paralysie complète qui dure plus de dix heures après l'opération.

Éléments cliniques : Nous croyons que la durée prolongée du BNM (plus de dix heures) est le résultat de fortes doses de médicaments de BNM combinées au sulfate de magnésium et à une insuffisance rénale modérée. L'âge avancé, la maladie hépatique, l'exposition aux aminoglycosides, l'hypocalcémie et une interaction possible entre le rocuronium et le pancuronium peuvent avoir jouer des rôles mineurs.

Conclusion : Nous devons éviter d'administrer de fortes doses d'agents de BNM, même quand une ventilation postopératoire planifiée. Si le BNM n'est pas surveillé chez les patients à risque de BNM pro- longé, la réponse en train-de-quatre doit alors être mesurée à l'unité des soins intensifs. Une sédation adéquate doit être donnée jusqu'à ce qu'une reprise convenable de la fonction neuromusculaire soit prouvée.

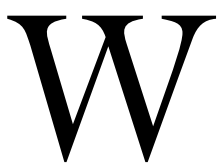

E examine two cases of prolonged neuromuscular blockade (NMB) after cardiac surgery. We attribute the extended durations of complete paralysis (more than ten hours) to high doses of NMB drugs in combination with magnesium sulphate and moderate renal failure.

\section{Case 1}

A 67-yr-old woman was referred to the anesthesia service for prolonged NMB after mitral valve replacement.

The patient had been transferred to our hospital for surgical treatment of bacterial endocarditis and critical mitral stenosis. The patient was treated initially for two weeks with ampicillin and gentamicin and one week of ampicillin alone. Her past medical history included rheumatic mitral valve stenosis (with previous commissurotomy), pulmonary hypertension and chronic atrial fibrillation. Height and weight were $165 \mathrm{~cm}$ and $63 \mathrm{~kg}$. Laboratory investigations revealed anemia, hypokalemia, and mild pre-renal failure (Table I). Preoperative medications included furosemide, digoxin, ramipril, iv heparin, flurazepam, ampicillin, and potassium chloride.

From the Department of Anesthesia, McGill University and McGill University Health Centre, Royal Victoria Hospital, Montreal, Quebec, Canada.

Address correspondence to: Dr. Gilles Plourde, Department of Anesthesia, MUHC - Royal Victoria Hospital, Room S5.05, 687 Pine

Avenue West, Montreal, Quebec H3A 1Al, Canada. Phone: 514-934-1934, ext. 34880; Fax: 514-843-1723;

E-mail: gilles.plourde@staff.mcgill.ca

No funding.

Accepted for publication March 22, 2004.

Revision accepted September 13, 2004. 
The patient underwent a redo mitral valve replacement during a five-hour procedure. Anesthesia was induced with midazolam $(8 \mathrm{mg})$, sufentanil $(100 \mu \mathrm{g})$ and pancuronium $\left(10 \mathrm{mg}=0.16 \mathrm{mg} \cdot \mathrm{kg}^{-1}\right)$ and was maintained with an infusion of midazolam $(10 \mathrm{mg})$, sufentanil $(250 \mu \mathrm{g})$ and pancuronium $(5 \mathrm{mg}=0.016$ $\left.\mathrm{mg} \cdot \mathrm{kg}^{-1} \cdot \mathrm{hr}^{-1}\right)$. Thus, a total of $15 \mathrm{mg}$ of pancuronium was given. Extra pancuronium boluses were not administered after induction and the infusion was completed at the intensive care unit (ICU) transfer. No anticholinesterase agent was given. Hypothermic $\left(32^{\circ} \mathrm{C}\right)$ cardiopulmonary bypass $(\mathrm{CPB})$ was used. The cross clamp time was $52 \mathrm{~min}$ and total perfusion time $91 \mathrm{~min}$. The patient received $3000 \mathrm{~mL}$ crystalloid solution, 500 $\mathrm{mL}$ pentastarch, and $6 \mathrm{U}$ packed red blood cells. The patient was weaned off $\mathrm{CPB}$ with low-dose norepinephrine and milrinone. Heparin (36000 U) was reversed with protamine $(500 \mathrm{mg})$. Magnesium sulphate $(2.5 \mathrm{~g})$ was administered $2.5 \mathrm{hr}$ before ICU transfer. The only other drugs given to the patient were vancomycin (1.5 $\mathrm{g}$ ), furosemide ( $40 \mathrm{~g})$, mannitol $(30 \mathrm{~g})$ remifentanil (500 $\mu \mathrm{g})$, and morphine $(10 \mathrm{mg})$. Urine output during the procedure was $400 \mathrm{~mL}$ and blood loss was $1800 \mathrm{~mL}$.

On ICU admission, the patient had slightly reactive pupils to light and no motor responses to painful stimuli. The patient was maintained on ventilatory support, warmed $\left(34.4^{\circ} \mathrm{C}\right.$ on arrival) and started on ampicillin $(2 \mathrm{~g} \mathrm{Q} 8 \mathrm{hr})$ and ticarcillin clavulanate (3.1 g Q $12 \mathrm{hr}$ ). In the first 12 postoperative hours, urine output was $305 \mathrm{~mL}$, despite the administration of furosemide (120 mg).

On postoperative day (POD) l ( $12 \mathrm{hr}$ after ICU admission), the patient was still completely unresponsive. No pain control or NMB drugs were given in the ICU. There were no deep-tendon, oculo-cephalic, or plantar reflexes. The pupils remained slightly reactive to light. The biochemical laboratory values were normal (Table I) and the cumulative urine output was $935 \mathrm{~mL}$ $(305+630 \mathrm{~mL})$ over $16 \mathrm{hr}$. The ICU staff consulted a neurologist, who agreed with the physical examination findings. A computed tomography (CT) scan of the head was ordered to rule out intracranial and/or brainstem pathology and anesthesia was asked to rule out prolonged NMB from the muscle relaxants given the day before.

Ulnar nerve stimulation at the wrist [train-of-four (TOF)] revealed no contraction of the adductor pollicis muscle $16 \mathrm{hr}$ after arrival to the ICU, despite appropriate current (> $50 \mathrm{~mA})$. Neostigmine $(2.5 \mathrm{~g})$ and glycopyrrolate $(0.6 \mathrm{~g})$ were given without change in the TOF response. A second dose produced a small muscle twitch. A propofol infusion was begun for sedation and the CT scan was cancelled.
By the end of POD 1 ( $24 \mathrm{hr}$ after ICU admission), the patient had recovered full neurological function. Tracheal extubation took place on POD 2 and transfer to the ward on POD 4. No other episode of neurological impairment occurred. The patient did suffer moderate renal failure (Table I). Her serum creatinine and urea, normally 63 and 5.7, peaked at 177 and 11.4, respectively, around POD 2. Likewise, mild elevations in serum liver enzymes were noted. The patient was discharged home on POD 15.

To estimate the plasma and effect-site concentrations of pancuronium, we used the program Stanpump (S. L. Shafer, Stanford University, Stanford, CA, USA version November 1996, http://anesthesia.stanford.edu/pkpd), with the Rupp-kinetic set for the elderly. The simulation used a bolus of $10 \mathrm{mg}$ followed by an infusion of $1 \mathrm{mg} \cdot \mathrm{hr}^{-1}$ for five hours. The predicted effect-site concentration of pancuronium on ICU arrival was $0.3 \mu \mathrm{g} \cdot \mathrm{mL}^{-1}$ (corresponding to $99 \%$ $\mathrm{NMB})$. The concentrations associated with $50 \%(0.12$ $\left.\mu \mathrm{g} \cdot \mathrm{mL}^{-1}\right)$ and $1 \%\left(0.05 \mu \mathrm{g} \cdot \mathrm{mL}^{-1}\right)$ blockade would have occurred at 2.8 and $6.3 \mathrm{hr}$ after ICU admission, respectively.

\section{Case 2}

A 78-yr-old woman was diagnosed with possible prolonged NMB after quadruple coronary artery bypass plus aortic root and valve replacement.

The patient presented to hospital for an elective coronary angiogram for chest pain investigation. Her past medical history included coronary artery disease, hypertension, hypercholesterolemia, and diabetes mellitus type II. Her height and weight were $152 \mathrm{~cm}$ and $69 \mathrm{~kg}$. Medications at admission included isosorbide mononitrate, omeprazole, nadolol, diltiazem XL, aspirin, and nitroglycerine spray.

The first injection of the right coronary artery caused an aortic dissection, which did not progress. The angiogram showed three-vessel coronary artery disease and an ejection fraction of $60 \%$. The patient underwent emergency cardiac surgery for $9.5 \mathrm{hr}$. Anesthesia was induced with midazolam $(5 \mathrm{mg})$, sufentanil $(75 \mu \mathrm{g})$ and rocuronium $(50 \mathrm{mg}=0.72$ $\left.\mathrm{mg} \cdot \mathrm{kg}^{-1}\right)$. It was maintained with sevoflurane $(0.5-1.0 \%)$ and an infusion of midazolam $(15 \mathrm{mg})$ plus sufentanil $(250 \mu \mathrm{g})$. A second dose of rocuronium $\left(30 \mathrm{mg}=0.43 \mathrm{mg} \cdot \mathrm{kg}^{-1}\right)$ was given six hours before ICU transfer. The patient also received three boluses of pancuronium: $5 \mathrm{mg}\left(0.072 \mathrm{mg} \cdot \mathrm{kg}^{-1}\right) 45$ min after induction, $5 \mathrm{mg}$ at the beginning of $\mathrm{CPB}$, and then $2 \mathrm{mg}\left(0.029 \mathrm{mg} \cdot \mathrm{kg}^{-1}\right)$ five hours before ICU transfer. No anticholinesterase agent was given. Hypothermic $\left(32^{\circ} \mathrm{C}\right) \mathrm{CPB}$ was used. The cross-clamp 
time was $196 \mathrm{~min}$ and total perfusion time $238 \mathrm{~min}$. The patient received $1000 \mathrm{~mL}$ crystalloid solution, $750 \mathrm{~mL}$ pentastarch, $8 \mathrm{U}$ packed red blood cells, $4 \mathrm{U}$ fresh frozen plasma, $6 \mathrm{U}$ platelets, and $6 \mathrm{U}$ cryoprecipitate. At the end of $\mathrm{CPB}$, the patient required cardiac pacing, an intra-aortic balloon pump (1:1), epinephrine (10 $\left.\mu \mathrm{g} \cdot \mathrm{min}^{-1}\right)$, norepinephrine (17.5 $\left.\mu \mathrm{g} \cdot \mathrm{min}^{-1}\right)$, and milrinone $\left(0.5 \mu \mathrm{g} \cdot \mathrm{kg}^{-1} \cdot \mathrm{min}^{-1}\right)$. Magnesium sulphate $(2.5 \mathrm{~g})$ was administered four hours before ICU transfer. The only other drugs given to the patient were vancomycin $(\mathrm{lg})$, furosemide $(40$ $\mathrm{mg})$, mannitol $(30 \mathrm{~g})$, aprotinin $(9450 \mathrm{mg})$, insulin (2 $\left.\mathrm{U} \cdot \mathrm{hr}^{-1}\right)$ and calcium chloride $(500 \mathrm{mg})$. At the end of the case, urine output was $1300 \mathrm{~mL}$, blood loss was $3000 \mathrm{~mL}$, and the cardiac index was $2.16 \mathrm{~L} \cdot \mathrm{min}^{-1} \cdot \mathrm{m}^{2}$.

On ICU admission, the patient was unconscious and her pupils were equal and non-reactive to light. The patient was maintained on ventilatory support and warmed $\left(35.3^{\circ} \mathrm{C}\right.$ on arrival). No additional doses of NMB agents were administered in the ICU. On POD 0 , the patient received vancomycin $1 \mathrm{~g}$, famotidine 20 $\mathrm{mg}$, amiodarone $150 \mathrm{mg}$, ticarcillin clavulanate $3.1 \mathrm{~g}$ TID, and furosemide $40 \mathrm{mg}$ BID. Urine output was $250 \mathrm{~mL}$ in the first two postoperative hours.

On POD 1 (11.5 hr after ICU admission), the patient was still completely unresponsive. The urine output was $795 \mathrm{~mL}$ (1045 mL since ICU admission) in the first eight hours of POD 1 and $540 \mathrm{~mL}(1585$ $\mathrm{mL}$ total) in the second eight hours. There were no deep-tendon, oculo-cephalic or plantar responses. The pupils were midsize, equal, and reactive to light. No contraction of the adductor pollicis muscle was elicited with ulnar nerve stimulation at the wrist, using both TOF and post-tetanic count. A trial of neostigmine $(3.5 \mathrm{mg})$ and glycopyrrolate $(0.7 \mathrm{mg})$ were given $13.5 \mathrm{hr}$ after ICU arrival. The patient was able to obey commands $3.5 \mathrm{hr}$ later. No further episodes of neurological impairment occurred. The patient remained on ventilatory support until POD 6 . Transfer to the ward took place on POD 11 and discharge home on POD 20.

The Stanpump simulation for pancuronium used boluses at minute $45(5 \mathrm{mg}), 105(5 \mathrm{mg})$, and $240(2$ $\mathrm{mg}$ ). The pancuronium simulation predicted an effect-site concentration of $0.08 \mu \mathrm{g} \cdot \mathrm{mL}^{-1}$ (corresponding to $12 \%$ blockade) on ICU arrival. The $1 \%$ blockade concentration of $0.05 \mu \mathrm{g} \cdot \mathrm{mL}^{-1}$ would have occurred two hours after ICU transfer. A second simulation was done with rocuronium, using boluses at minute zero $(50 \mathrm{mg})$ and $180(30 \mathrm{mg})$. The rocuronium simulation yielded a predicted effect-site concentration of $0.02 \mu \mathrm{g} \cdot \mathrm{mL}^{-1}$ (corresponding to approximately $0 \%$ blockade $)^{1}$ on ICU arrival. The sim- ulations did not account for the additive effects of combining pancuronium and rocuronium.

\section{Discussion}

Residual NMB after cardiac surgery is well-documented. ${ }^{2-4}$ Its occurrence is not surprising given the numerous predisposing factors associated with cardiac surgery: long-acting neuromuscular blocking agents, planned postoperative ventilation, magnesium sulphate, co-morbidities, advanced age, hypothermic $\mathrm{CPB}$, volatile agents, acidosis, hypocalcemia, aminoglycosides, vancomycin, furosemide, mannitol, betablockers, and calcium channel blockers. ${ }^{5}$ To the best of our knowledge, however, these are the first reported cases of complete paralysis lasting more than ten hours after cardiac surgery.

The dose and type of drugs used in the operating room are the primary determinants of $\mathrm{NMB}$ duration. ${ }^{6}$ The doses of neuromuscular blocking agents given to the patients were high. The first patient received $15 \mathrm{mg}$ of pancuronium $\left(0.048 \mathrm{mg} \cdot \mathrm{kg}^{-1} \cdot \mathrm{hr}^{-1}\right)$, while the second patient received $80 \mathrm{mg}$ of rocuronium $\left(0.12 \mathrm{mg} \cdot \mathrm{kg}^{-1} \cdot \mathrm{hr}^{-1}\right)$ and $12 \mathrm{mg}$ of pancuronium $\left(0.018 \mathrm{mg} \cdot \mathrm{kg}^{-1} \cdot \mathrm{hr}^{-1}\right)$. In the second patient, potentiation of neuromuscular activity between rocuronium and pancuronium may have occurred, but if so, the impact would have been low. Isobolographic analysis demonstrates an additive (and not synergistic) response between rocuronium and pancuronium. ${ }^{6}$ Therefore, even in the context of high steroidal NMB drug doses, the durations of NMB were considerably longer than predicted by pharmacokinetic and pharmacodynamic modeling. Furthermore, the actual drug concentrations may have been lower than predicted because the simulations did not include drug elimination by blood loss and drug dilution by CPB, $i v$ fluids and blood products.

The drug that most likely increased the duration of muscle relaxation was magnesium sulphate. Both patients received $2.5 \mathrm{~g}$ of magnesium sulphate for its anti-arrhythmic properties. Increased levels of serum magnesium followed the timeframe during which the patients remained paralyzed (Tables I and II). Magnesium prolongs NMB by inhibiting the release of acetylcholine at the nerve terminal. ${ }^{7}$ In a study considering the effects of magnesium sulfate on NMB, Fuchs-Buder, et al. ${ }^{7}$ showed that recovery from vecuronium with neostigmine was decreased by $30 \%$ in obstetrical patients pretreated with magnesium sulphate. Similarly, in a case report by Kwan et al. ${ }^{8}$ therapeutic serum magnesium levels in a woman with severe pre-eclampsia prolonged the effect of $1 \mathrm{mg}$ of vecuronium to four hours. These findings are consis- 
TABLE I Case 1 laboratory values

\begin{tabular}{|c|c|c|c|c|c|c|}
\hline Labs & Admission & Preop & POD 0 & POD 1 & POD 2 & POD 3 \\
\hline $\mathrm{Hb}\left(\mathrm{g} \cdot \mathrm{L}^{-1}\right)$ & 89 & 82 & 101 & & 89 & \\
\hline $\operatorname{Hct}\left(\mathrm{L} \cdot \mathrm{L}^{-1}\right)$ & 0.27 & 0.25 & 0.29 & & 0.27 & \\
\hline $\mathrm{WBC}\left(10^{9} \cdot \mathrm{L}^{-1}\right)$ & 7.31 & 7.17 & 17.41 & & 7.31 & \\
\hline Plts $\left(10^{9} \cdot \mathrm{L}^{-1}\right)$ & 89 & 164 & 77 & & 189 & \\
\hline $\operatorname{INR}(0.8-1.20)$ & 1.28 & 1.08 & 1.90 & 1.25 & 1.19 & \\
\hline PTT $(27.0-40.9 \mathrm{sec})$ & 56.9 & 43.3 & 74.8 & & & \\
\hline $\mathrm{Na}\left(\mathrm{mmol} \cdot \mathrm{L}^{-1}\right)$ & 140 & 143 & 143 & & & \\
\hline $\mathrm{K}\left(\mathrm{mmol} \cdot \mathrm{L}^{-1}\right)$ & 2.8 & 3.5 & 3.4 & & & \\
\hline $\mathrm{Cl}\left(\mathrm{mmol} \cdot \mathrm{L}^{-1}\right)$ & 102 & 106 & 113 & & & \\
\hline $\mathrm{HCO}_{3}\left(\mathrm{mmol} \cdot \mathrm{L}^{-1}\right)$ & 30 & 28 & 22.6 & & & \\
\hline $\operatorname{Urea}\left(\mathrm{mmol} \cdot \mathrm{L}^{-1}\right)$ & 6.3 & 4.6 & 5.0 & 6.2 & 9.5 & 11.4 \\
\hline Creatinine $\left(\mathrm{umol} \cdot \mathrm{L}^{-1}\right)$ & 104 & 73 & 97 & 153 & 177 & 158 \\
\hline Glucose $\left(\mathrm{mmol} \cdot \mathrm{L}^{-1}\right)$ & 5.4 & 5.2 & 9.4 & 12.9 & 7.0 & 6.9 \\
\hline $\mathrm{Mg}\left(\mathrm{mmol} \cdot \mathrm{L}^{-1}\right)$ & 0.83 & 2.26 & 1.71 & 1.39 & 1.25 & 0.96 \\
\hline $\mathrm{Ca}\left(\mathrm{mmol} \cdot \mathrm{L}^{-1}\right)$ & 2.19 & 1.17 & & & & \\
\hline $\mathrm{PO}_{4}\left(\mathrm{mmol} \cdot \mathrm{L}^{-1}\right)$ & 0.89 & 1.31 & & & & \\
\hline Albumin $\left(\mathrm{g} \cdot \mathrm{L}^{-1}\right)$ & & & 15 & & & \\
\hline Total bilirubin $\left(\mathrm{umol} \cdot \mathrm{L}^{-1}\right)$ & & & 22.20 & 32.37 & 15.66 & 12.9 \\
\hline $\operatorname{AST}\left(U \cdot L^{-1}\right)$ & & & 120 & 161 & 108 & 77 \\
\hline Amylase $\left(\mathrm{U} \cdot \mathrm{L}^{-1}\right)$ & & & 145 & 807 & & 454 \\
\hline $\mathrm{pH}$ & & & 7.46 & & & \\
\hline
\end{tabular}

POD = postoperative day; $\mathrm{Hb}=$ hemoglobin; $\mathrm{Hct}=$ hematocrit $\mathrm{WBC}=$ white blood cells; Plts = platelets; INR = international normalized ratio; PTT $=$ partial thromboplastin time.

tent with those published by Kussman et al., who demonstrated increased durations of NMB in patients given magnesium sulphate before rocuronium ${ }^{9}$ and with those published by Pinard et al., who showed prolonged NMB in cardiac surgery patients given magnesium sulphate and cisatracurium. ${ }^{10}$ Lastly, it is interesting to note that the patients' postoperative serum calcium levels were low. Since calcium has the potential to reverse the effect of magnesium at the nerve terminal, low serum calcium may be an additional contributory factor. ${ }^{11}$

Renal function was probably the dominant patient factor that contributed to the long durations of NMB (Tables I and II). Although renal failure likely prolonged the effects of the NMB agents, it is difficult to imagine that moderate postoperative renal impairment explains complete paralysis lasting greater than ten hours. Increased age and mildly abnormal liver function are other patient factors that may have played limited roles.

In the first case, an aminoglycoside was administered, but then stopped one week before surgery. The effect of this drug was likely minimal. Aminoglycosides can produce a curare-like NMB in animals at serum concentration levels higher than those obtained with conventional dosing (1-2 $\mathrm{mg} \cdot \mathrm{kg}^{-1}$ every eight hours). ${ }^{12}$ According to Wong et al., these blocks are rarely encountered clinically. ${ }^{12}$

In summary, the most likely cause of prolonged $\mathrm{NMB}$ was the combined use of magnesium sulphate with high doses of $\mathrm{NMB}$ in patients with moderate renal failure. The other factors (NMB agent potentiation, hypocalcemia, age, hepatic function) likely had minor effects. We should avoid administering large doses of NMB agents, even in the context of planned postoperative ventilation. Excessive doses of long-acting muscle relaxants may increase the duration of postoperative ventilation and lead to prolonged, undetected intraoperative awareness. ${ }^{13}$

Neuromuscular function is not routinely monitored during cardiac surgery, ${ }^{14}$ a trend that is probably influenced by planned postoperative ventilation and lack of access to the adductor pollicis muscle. TOF stimulation of the temporal branch of the facial nerve is a possible method to monitor NMB intraoperatively, but the risk of overdosing patients with muscle relaxants still exists. The orbicularis oculi is more resistant to non-depolarizing agents than the adductor pollicis and direct facial muscle stimulation can occur unintentionally around the eye. ${ }^{4}$ Alternative techniques, such as phonomyography, ${ }^{15}$ have been proposed for monitoring NMB during cardiac surgery, 
TABLE II Case 2 laboratory values

\begin{tabular}{|c|c|c|c|c|c|}
\hline Labs & Preop & POD 0 & $P O D 1$ & POD 2 & POD 3 \\
\hline $\mathrm{Hb}\left(\mathrm{g} \cdot \mathrm{L}^{-1}\right)$ & 116 & 88 & $64-94$ & & \\
\hline $\operatorname{Hct}\left(\mathrm{L} \cdot \mathrm{L}^{-1}\right)$ & 0.34 & 0.24 & & & \\
\hline $\operatorname{WBC}\left(10^{9} \cdot \mathrm{L}^{-1}\right)$ & & 16.4 & $9.8-15.8$ & & \\
\hline Plts $\left(10^{9} \cdot \mathrm{L}^{-1}\right)$ & 434 & 188 & $98-237$ & & \\
\hline $\operatorname{INR}(0.8-1.20)$ & 1.07 & 2.0 & $1.4-1.6$ & & \\
\hline PTT $(27.0-40.9 \mathrm{sec})$ & 30.9 & 77.8 & $47-63$ & & \\
\hline $\mathrm{Na}\left(\mathrm{mmol} \cdot \mathrm{L}^{-1}\right)$ & 141 & 149 & 147 & 137 & \\
\hline $\mathrm{K}\left(\mathrm{mmol} \cdot \mathrm{L}^{-1}\right)$ & 4.6 & 4.0 & 3.2 & 3.9 & \\
\hline $\mathrm{Cl}\left(\mathrm{mmol} \cdot \mathrm{L}^{-1}\right)$ & 111 & 111 & 111 & 107 & \\
\hline $\mathrm{HCO}_{3}\left(\mathrm{mmol} \cdot \mathrm{L}^{-1}\right)$ & & 27 & 28 & 23.9 & 24 \\
\hline Urea $\left(\mathrm{mmol} \cdot \mathrm{L}^{-1}\right)$ & 12.2 & 8.1 & 9.7 & 13.9 & 12.1 \\
\hline Creatinine $\left(\mathrm{umol} \cdot \mathrm{L}^{-1}\right)$ & 111 & 105 & 88 & 190 & 129 \\
\hline Glucose $\left(\mathrm{mmol} \cdot \mathrm{L}^{-1}\right)$ & 6.6 & 12.4 & 11.1 & 4.3 & 6.3 \\
\hline $\operatorname{Mg}\left(\mathrm{mmol} \cdot \mathrm{L}^{-1}\right)$ & & 1.8 & 1.27 & 0.90 & 1.30 \\
\hline $\mathrm{Ca}\left(\mathrm{mmol} \cdot \mathrm{L}^{-1}\right)$ & & & 1.74 & 1.59 & 1.54 \\
\hline $\mathrm{PO}_{4}\left(\mathrm{mmol} \cdot \mathrm{L}^{-1}\right)$ & & 0.97 & 0.76 & 1.93 & 1.49 \\
\hline Albumin $\left(\mathrm{g} \cdot \mathrm{L}^{-1}\right)$ & & 19 & 17 & 22 & 21 \\
\hline Total bilirubin $\left(\mathrm{umol} \cdot \mathrm{L}^{-1}\right)$ & & 62.0 & 33.9 & 73.75 & 54.9 \\
\hline $\operatorname{AST}\left(\mathrm{U} \cdot \mathrm{L}^{-1}\right)$ & & & 136 & 419 & 482 \\
\hline Amylase $\left(\mathrm{U} \cdot \mathrm{L}^{-1}\right)$ & & 70 & 91 & 518 & 420 \\
\hline $\mathrm{pH}$ & & 7.46 & & & \\
\hline
\end{tabular}

$\mathrm{POD}=$ postoperative day $\mathrm{Hb}=$ hemoglobin; $\mathrm{Hct}=$ hematocrit $\mathrm{WBC}=$ white blood cells; Plts = platelets; INR = international normalized ratio; PTT $=$ partial thromboplastin time .

yet these techniques are not used widely. If NMB is not monitored intraoperatively in patients who are at risk of prolonged $\mathrm{NMB},{ }^{13}$ then TOF response should be measured in the ICU. Adequate sedation should be provided until proper recovery of neuromuscular function is documented.

\section{References}

1 Saldien V, Vermeyen KM, Wuyts FL. Target-controlled infusion of rocuronium in infants, children, and adults: a comparison of the pharmacokinetic and pharmacodynamic relationship. Anesth Analg 2003; 97: 44-9.

2 Van Oldenbeek C, Knowles P, Harper NJ. Residual neuromuscular block caused by pancuronium after cardiac surgery. Br J Anaesth 1999; 83: 338-9.

3 McEwin L, Merrick PM, Bevan DR. Residual neuromuscular blockade after cardiac surgery: pancuronium vs rocuronium. Can J Anaesth 1997; 44: 891-5.

4 Murphy GS, Szokol JW, Marymont JH, et al. Recovery of neuromuscular function after cardiac surgery: pancuronium versus rocuronium. Anesth Analg 2003; 96: 1301-7.

5 Donnelly AJ, Cunningham FE, Baughman VL. Anesthesiology and Critical Care Drug Handbook, 3rd ed. Hudson: Lexi-Comp Inc.; 2000.

6 Naguib M, Samarkhandi H, Bakhamees HS, Magboul $M A, E l$-Bakry AK. Comparative potency of steroidal neuromuscular blocking drugs and isobolographic analysis of the interaction between rocuronium and other aminosteroids. Br J Anaesth 1995; 75: 37-42.

7 Fuchs-Buder T, Ziegenfub T, Lysakowski K, Tassonyi E. Antagonism of vecuronium-induced neuromuscular block in patients pretreated with magnesium sulphate: dose-effect relationship of neostigmine. Br J Anaesth 1999; 82: 61-5.

8 Kwan WF, Lee C, Chen BJ. A noninvasive method in the differential diagnosis of vecuronium-induced and magnesium-induced protracted neuromuscular block in a severely preeclamptic patient. J Clin Anesth 1996; 8: 392-7.

9 Kussman B, Shorten G, Uppington J, Comunale ME. Administration of magnesium sulphate before rocuronium: effects on speed of onset and duration of neuromuscular block. Br J Anaesth 1997; 79: 122-4.

10 Pinard AM, Donati F, Martineau R, Denault AY, Taillefer J, Carrier M. Magnesium potentiates neuromuscular blockade with cisatracurium during cardiac surgery. Can J Anesth 2003; 50: 172-8.

11 Feldman S, Karalliedde L. Drug interactions with neuromuscular blockers. Drug Saf 1996; 15: 261-73.

12 Wong J, Brown G. Does once-daily dosing of aminoglycosides affect neuromuscular function? J Clin Pharm Ther 1996; 21 : 407-11.

13 Heier T, Steen PA. Awareness in anaesthesia: incidence, 
consequences and prevention. Acta Anaesthesiol Scand 1996; 40: 1073-86.

14 Murphy GS, Szokol JW, Vender JS, Marymont JH, Avram MJ. The use of neuromuscular blocking drugs in adult cardiac surgery: results of a national postal survey. Anesth Analg 2002; 95: 1534-9.

15 Hemmerling TM, Michaud G, Babin D, Trager G, Donati F. Comparison of phonomyography with balloon pressure mechanomyography to measure contractile force at the corrugator supercilii muscle. Can J Anesth 2004; 51: 116-21.

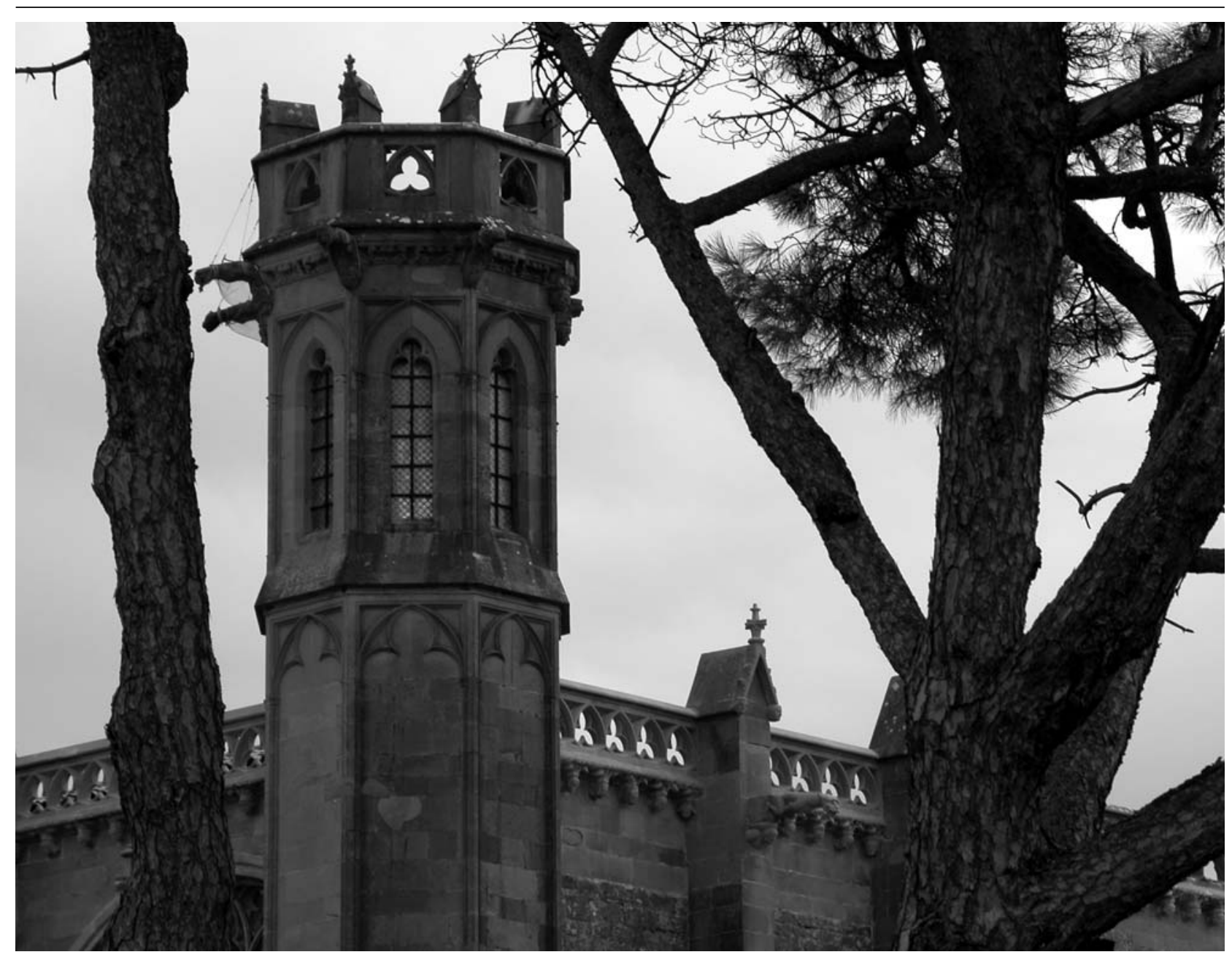

Carcassonne - France 